\title{
ファジィ協調法に基づく大規模電力システム の多目的最適運用
}

$\begin{array}{lllll}\text { 正員 前 川 } & \text { 友 } & \text { (東京都立大) } \\ \text { 正員 安 } & \text { 田 } & \text { 恵一郎 } & \text { (東京都立大) } \\ \text { 正員 横 山 } & \text { 隆 一 } & \text { (東京都立大) } \\ \text { 正員 水 上 } & \text { 雄 一 } & \text { (関西電力) } \\ \text { 正員 横 山 } & \text { 尚 登 } & \text { (関西電力) }\end{array}$

Multi-Objective Optimal Operation of Large Scale Power System Based on Fuzzy Coordination Technique

Tomochika Maekawa, Member, Keiichiro Yasuda, Member, Ryuichi Yokoyama, Member (Tokyo Metropolitan University), Yuichi Mizukami, Member, Naoto Yokoyama, Member (Kansai Electric Power Co., Inc)

This paper presents an approach to obtain the optimal generation dispatch in real power system operation by solving a multi-objective optimization problem. In deciding the optimal system operation, various objectives, such as economy, quality and environmental impact, should simultaneously be attained. However, these objectives are contradictory to each other and are in trade-off relations, thus making it difficult to handle this class of problem. In the recent study, we were proposed the algorithm to treat the multi-objective optimal dispatch problems using the fuzzy coordination technique.

In the foregoing approach, however, optimization is successively conducted by nonlinear programming and the computation time is extensively increases as the size of the target power system is expanded. Thus, for the practical application of this approach to a real-scale system, we need to resort to a high-speed approximation for the reduction of computation time and storage requirement.

In this study, we propose the approach decomposed into static dispatch and dynamical adjustment so that we can apply it to a relatively large scale system. In this approach we can obtain an optimal solution by satisfying some predetermined optimality conditions, thus enabling rapid convergence and application to a real-scale system.

The effectiveness of the proposed approach is verified through numerical analysis on the test system approximating the system of Kansai Electric Power Company.

キーワード：電力系統，ファジィ理論，多目的計画問題，経済負荷配分，起動停止，AFC 調整容量

\section{1.はじめに}

近年の電力系統の運用においては，経済性の追求の みにとどまらず，その他の多椂な社会的要求をも勘案
した運用をなすことが必要となってきている。從っ て, 発電費用のみを指摽とした経済負荷配分（Economic Load Dispatch ; ELD) による運用では他の要 求が考慮されないため, 複数の目的を協調させること 
が可能な運用手法の導入が必要となる。しかし，複数 の目的を考慮する場合，一つの目的を達成しようとす ると他の目的を檥牲にしなければならないといったト レードオフ関係が存在する。しかも，これらの達成目 的間には明確な優先順位が存在しないために, 従来か らの単一目的を対象とする手法では，こうした問題を 取扱うことが困難であった ${ }^{(1)}$ 。

このような問題点を解決するために，複数の目的を もつ問題を多目的計画問題 (Multi-Objective Programming；MOP）として定式化し，ファジィ協調 法による最適運用状態を決定する手法を提案してき た。こうした手法を用いて，経済性，環境性などの複 数の達成目的を協調した運用が可能であることを示し てきだ2)。

また，大容量原子力がバース負荷の大部分をになっ ている大規模電力系統では, 通常, 火力発電機はミド ル負荷あるいはピーク負荷をになうことになる。この ため, 火力発電機群は急睃な負荷変動に対応できるこ とが要求される。更に，周波数偏差を極力吸収できる ような出力調整能力を保持していることが望ましい。 しかし, 通常の運転では負荷上昇時には, 発電費用の 低い発電機の出力が優先的に增加されるため,これら の発電機群の一部虫力上限值に張りついて, 系統全 体としての出力調整能力が低下してしまうことが考元 られる。また，通常の系統運用では周波数変動に対処 するためAFC (Automatic Frequency Control；自 動周波数制御）がかけられているが， $\mathrm{AFC}$ 運用を行 うためには, 出力增加方向にも減少方向にも数\%程度 の調整容量を確保して扝くことが必要となる。通常, $\mathrm{AFC}$ 調整容量は，あらかじめ制約をかけておくこと によって確保する方法がとられている。しかし，現実 にはこのように AFC 調整容量を厳密に制約として設 定する必要性は乏しいと考えられるため，この部分の 制約をあいまいにした多目的運用手法がこれまでに開 発されている(3)(4)。

本研究では，AFC 調整容量は出力調整幅の一部で あると考え， $\mathrm{AFC}$ 調整容量をあらかじめ制約として 設定することは行わず，経済性なども考慮しながら出 力調整余力をできるだけ確保するといった柔軟な運用 をなすことを試みる。従って，出力調整容量の確保を 達成目的の一つであると考兄，これを目的関数として 取込んだ多目的動的運用に関する手法を提案する。

しかし，本手法を実規模系統に適用するにあたつ て, 系統規模の増大に伴い所要計算時間が膨大に增加 し, 通常の計算機利用環境下での計算が困難となる, あ るいは, 運用計算の対象とすることができる時間帯が
極めて短時間の場合に限られることになるといった 問題点が生じてきた。

このような点を考虑し，本研究で開発された運用計 算手法を実規模系統に適用するためには，計算時間を 短縮するため高速近似解法を導入することが必要であ る(5)。そこで, 本研究で用いられている評価指標は主 として二次関数の形式で表現されていることに着目 し,すべての評価指標を二次関数で近似し, 最適解を 解析的に得ることのできるラグランジュ未定乗数法を 用いた手法を導入する。

更に，運用計算の対象とする時閒带をできるだけ長 期にするため, 発電機の起動停止を考慮した手法を導 入する。これは, 実際の運用においては需要の大きさ に応じて発電機の運転台数を変更しているという現害 に対応したものである。このため，1日の運用を考慮 するにあたっては，発電機の起動パターンを考慮した 運用が取扱える必要がある。本研究では，この起動停 止決定手法として, 優先順位法を用いた。

上述のように，本論文ではファジィ協調法に基づく 電力系統の多目的運用手法を実規模系統へ適用するた め, 最適解を解析的に求める高速近似解法を導入す る。また, 発電機の起動パターンをも考慮することに より，対象となる期間が長時間にわたる運用計算が可 能となる手法を提案する。更に，本手法を関西電力の 実系統に適用し，その有効性を検証する。

\section{2. 優先順位法による発電機の起動停止決定}

火力発電機は，起動停止を伴うと起動損失と呼ばれ る熱損失などがあるため，できるだけ連続運転するこ とが望ましい。しかし，実際には1日における負荷需 要量は昼夜間の差が大きく, 夜間には一部の発電機を 停止し翌朝起動するDSS（Daily Start Stop；毎日起 動停止）を行うのが普通である。火力発電機は，最低 負荷運転時に比へて定格負荷運転時には熱効率が向上 するので，できるだけ定格負荷運転となるように並 列, 解列の時期を選定する必要がある。このように, 与えられた予測負荷に対して，通常，経済性を考慮し た発電機の起動停止パターンが決定される(6)。

優先暊位法による発電機起動停止決定手法では, あ らかじめ何らかの方法で発電機の並列順位を決定して おき，新たに発電機の起動が必要な場合には，優先順 位の高い発電機から順次系統に並列していく。また， 発電機の停止が必要な場合は, 優先順位の低いものか ら順次解列していくことになる。従って, 本手法で 発電機の起動費を考慮した最適な起動停止を同時に決 定することはできないが，優先順位に従った起動停止 
があらかじめ以下のように決定されるため，この起動 停止パターンに従って, 起動費を計算することもでき る。

優先順位があらかじめ決められているものとする と, 発電機の起動台数は以下のように決定できる。

まず，予測される負荷需要に対して，負荷をになう ことのできる発電機台数の集合を決定する。このと き,ピーク時には約 10\%程度の予備力を確保できる ように，䒠際の予測負荷よりも予備力分だけ多めの負 荷でもとれるだけの発電機台数を起動するものとす る。従って, 次式を満足する $N(t)$ の集合を, 時刻 $t$ における寒行可能な起動台数の集合とする。

$$
\sum_{i=1}^{N(t)} \underline{P}_{i} \leqq P_{L}(t)+P_{S_{R}}(t) \leqq \sum_{i=1}^{N(t)} \bar{P}_{i}
$$

$\bar{P}_{i}, \underline{P}_{i}$ : 第 $i$ 発電機の出力上下限値 $(\mathrm{pu})$

$N(t)$ : 第 $t$ 時間带の発電機の起動台数（台）

$P_{E}(t)$ : 第 $t$ 時間帯の総需要量 $(\mathrm{pu})$

$P_{S R}(t)$ : 第 $t$ 時間帯の予備力 $(\mathrm{pu})$

このように決定された実行可能な起動台数のすべて の場合について, 最経済に運用されたときの総燃料費 を計算し，この総燃料費が最も小さくなる発電機の組 合せをその時点での起動台数とする。

また，優先順位の決定方法としては，幾つかの方法 があると考えられるが，本研究では，火力発電機は定 格出力時に最経済となるように設計されていることに 着目し, 定格出力時の単位出力当たりの発電費用を計 算し，これに基づいて優先順位を決定した。

すなわち，次式のような評価関数を与え，これに基 づいて優先顒位の決定を行う。

$$
f_{\mathrm{prt}}=\frac{f_{c}\left(P_{i}^{n}\right)}{P_{i}^{n}}
$$

$f_{\mathrm{pr} 1}$ ：優先順位決定のための評価指標, $P_{i}^{n}$ :

第 $i$ 発電機の定格出力 $(\mathrm{pu}), f_{c}$ : 第 $i$ 発電 機の燃料費 $(\mathrm{pu})$

\section{3. ファジィ協調法による最適化}

ファジィ協調法とは，多目的計画問題の各目的関数 に意思決定者のファジィ目標を特性づける「メンバシ ッフ関数」を設定し，それらの関数を統合させること によって通常の最大化問題に䚻着させ, 多目的最適解 を得る手法である(7)。すなわち，各目的関数に対して 図1のようなメンバシップ関数を定義し，これらを統 合した関数（ファジィ決定関数）の最大化問題を解く ことにより，最適解を決定することができる。これ は，一般の数理計画法にファジイ理論を適用した「フ アジィ数理計画法」に基づいている。このような問題

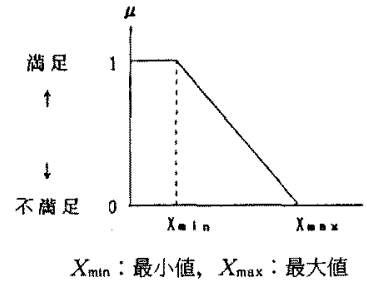

図 1 メンバシッッフ関数

Fig. 1. Membership function.

は，次に示すファジィ決定関数の最大化問題を解くこ とによって，最適解を決定することができる。

$$
\left.\begin{array}{l}
\max \left[F_{D M}(\boldsymbol{x})\right] \\
F_{D M}(\boldsymbol{x})=\sum_{i=1}^{N}\left\{\mu_{i}\left\{f_{i}(x)\right\}\right] \\
\text { subj. to } \quad \boldsymbol{x} \in \boldsymbol{X}
\end{array}\right\}
$$

$F_{D M}:$ ファジィ決定関数, $\boldsymbol{X}: \boldsymbol{x}$ の実行可能

解の集合, $\mu_{i}:$ メンバシップ関数, $f_{i}(x)$ :

各目的つ評価関数

ファジィ協調法では，各目的ごとに定式化を行うこ とができるため, 問題の記述が容易になり, 多目的計 画問題を効率良く解くことができる。また，各目的ご との達成度を，メンバシップ関数という形で数值的に 表すことができるため，運用者の意思を反映すること が可能となり，解の定量的な評洒も容易に行える。

\section{4. 定 式 化}

〈4・1〉評価指標の定式化 出力調整容量の評価 指標, 経済性指標, 環境性指標については以下に述べ るような二次関数によって定式化される。このよう に，評価指標を二次関数で表現すると，ファジィ協調 法を用いて多目的最適解を求める際に用いるファジィ 決定関数も二次関数となるため，最適解を容易に求め ることができる。

（1）出力調整容量 出力調整を伴う発電機は, 負荷が増加したときにも隇少したときにも対応できる ことが必要であるため, 現運転点からの出力の増加方 向だけでなく滅少方向にも調整余力を確保して扔かな ければならない。

従って,

(i) 現時点の出力と出力上限值との差

(ii) 現時点の出力と出力下限值との差 のうちいずれか小さいほうを現時点て確保されている 調整容量であると考えると，(4)式のように定式化で きる。このように, 出力調整が可能な発電機各々につ いて, 出力調整幅をある程度確保しておくことによ 


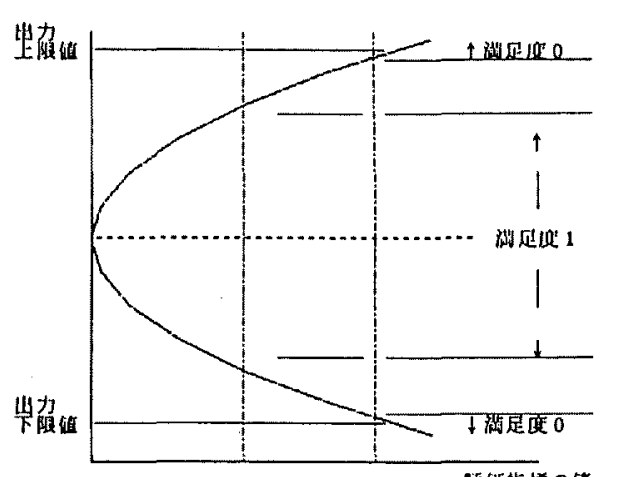

(a) 出力語整容量の訶牺関数

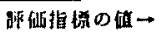

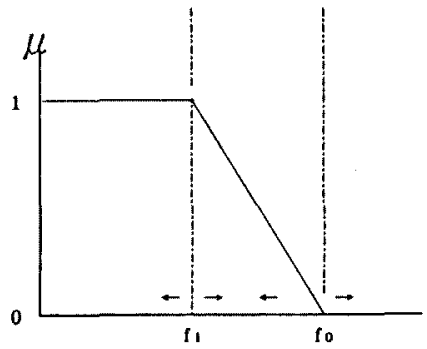

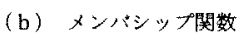

図 2 出力調整容量の評価指標

Fig. 2. Evaluation index of regulation capacity.

り，予測值を上回る負荷変動に対しても調整が可能で ある。

$$
F_{R}(t)=\sum_{i=1}^{K(t)} \min \left(\bar{P}_{i}-P_{G i(t)}, P_{G i(t)}-\underline{P}_{i}\right)
$$

$F_{R}(t)$ : 第 $t$ 時間帯の調整容量評価指標

$P_{G i(t)}$ : 第 $t$ 時間帯の発電機 $i$ の有効出力 (pu)

$\bar{P}_{i}, \underline{P}_{i}$ : 発電機 $i$ の出力上下限值 $(\mathrm{pu})$

$K(t)$ : 調整用発電機の台数（台）

上記の (4) 式は離散関数となるため取扱いが困難で あり，特に本手法に扔いては最適解の決定にラグラン ジュ未定乗数法を用いているため，取扱うことができ ない。従って, 二次関数で近似した発電機の調整容量 を評価するための評価指標を導入する必要がある。

そこで，以下に示すような評価指標を導入する。

$$
F_{R}(t)=\sum_{i=1}^{K(t)}\left(P_{G i(t)}-\frac{\bar{P}_{i}+P_{i}}{2}\right)^{2}
$$

上式を図示すると図 2 のうになる。発電機出力が 出力上限值あるいは出力下限值に等しいときは, この 評価指標の值は最大になる。このように出力が上下限 值に張りついている場合は, 一方向にしか出力変化で
きないため, 調整容量は全く確保されていないと考え られる。

発電機出力が出力上限値または出力下限值から遠ざ かるにつれて評価指標の值は減少し, 発電機出力が出 力上下限值の中間の值をとるときに評価指標は最小と なる。このように, 出力上下限值の中間の值をとると き, 出力の増加方向にも減少方向にも最大限の出力 変化が可能であるため, この運転点では最大の調整容 量が得られていると考无ることができる。従って,こ の指標を最小化することによって最適化が図られるこ とになる。

評価指標とメンバシップ関数との関連は図 2 に示す と扔りである。すなわち，系統運用者が最大限満足で る場合の評価指標の値と最小限許容できる場合の評 価指標の值を，それぞれメンバシップ関数のパラメー タとして設定する。このように，系統運用者の選好を メンバシップ関数に反映させることにより，運用者の 意思を反映した系統運用を試みることができる。

（2）経済性指標 経済性指標としては，火力発 電機の燃料費を考える。火力発電機の燃料費特性関数 は, 通常次のように発電機出力の二次関数として近似 される

$F_{c}(t)=\sum_{i=1}^{N(t)}\left(\alpha_{i} P_{C i(t)}^{2}+\beta_{i} P_{C i(t)}+\gamma_{i}\right)$

$F_{c}(t)$ : 対象期間での総発電燃料費用 (円)

$P_{G_{i}(t)}:$ 第 $t$ 時間带の発電機 $i$ の有効出力 $(\mathrm{pu})$

$\alpha_{i}, \beta_{i}, \gamma_{i}$ : 第 $i$ 発電機の発電营用特性係数

$N(t)$ : 第 $t$ 時間带で運転中の発電機台数 (台)

(3) $\mathrm{NO}_{x}$ 排出量特性関数環境保全に対する 指標として, 窒素酸化物 $\left(\mathrm{NO}_{x}\right)$ 排出量を用いる。 これは, 発電機出力の二次関数と指数関数の和で表さ 机る(9)。

$$
\begin{aligned}
F_{R}(t)= & \sum_{i=1}^{N(t)}\left[a_{i} P_{G i(t)}^{2}+b_{i} P_{G i(t)}+c_{i}\right. \\
& \left.+d_{i} \exp \left(e_{i} P_{G i(t)}\right)\right] \quad \ldots \ldots . .
\end{aligned}
$$

$F_{R}(t)$ : 対象期間での $\mathrm{NO}_{x}$ 排出量 $(\mathrm{t})$

$P_{G i(t)}$ : 第 $t$ 時間帯の発電機 $i$ の有効出力 $(\mathrm{pu})$

$a_{i}, b_{i}, c_{i}, d_{i}, e_{i}$ : 第 $i$ 発電機の排出量特

性係数, $N(t)$ : 運転中の発電機台数 (台)

本手法では, 最適解決定に扔いてラグランジュ末定 乗数法を用いるため, 評価指標を各発電機出力の二次 関数として設定することが必要となる。従って, 次式 のと扔り出力の二次式で近似する。

$$
F_{R}(t)=\sum_{i=1}^{N(t)}\left(a_{i} P_{G i(t)}^{2}+b_{i} P_{G i(t)}+c_{i}\right)
$$

〈4・2〉制約式の定式化 有効電力配分に拈いて 
は，需給平衡を満足したうえで，発電機出力の上下限 制約，発電機の応答速度などを考慮する必要がある。 これは，次のように定式化される。

（1）需給バランス制約 電力の供給において は，需要と供給のバランスを保つために，すべての時 間带において発電機出力の総和は, 負荷需要の総和に 一致していなければならない。

$$
\sum_{i=1}^{N} P_{G i(t)}=P_{D(t)} \quad(t=1,2, \cdots, T)
$$

$P_{D(t)}:$ 第 $t$ 時間帯の総需要量 $(\mathrm{pu})$

（2）発電機出力上下限制約 個々の発電機に は，それぞれ供給できる出力の上下限があり，この範 囲内でそれぞれの発電機は，負荷を分担しなければな らない。

$$
\underline{P}_{G i} \leqq P_{G i(t)} \leqq \bar{P}_{G i} \quad(i=1,2, \cdots, n)
$$

$\underline{P}_{G i}, \bar{P}_{G i}$ : 発電機出力の下限, 上限值 $(\mathrm{pu})$

（3）発電機応答速度制約 各時間ごとに負荷が 変動するような動的なモデルでは, 発電機出力の応答 速度を考慮する必要がある。すなわち，発電㙨の単位 時間当たりの出力変化量は発電機の応答限界を超える ことはできない(10)。

$$
\begin{aligned}
& \Delta P_{G i} \leqq P_{G i(t)}-P_{G i(t-1)} \leqq \Delta \bar{P}_{G i} \\
& (i=1,2, \cdots, n)
\end{aligned}
$$

\section{5. 実規模系統への適用}

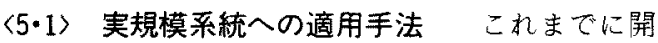
発してきた手法は, 前章で示した定式化を用いてファ ジィ決定関数を定義し，これに対して非線形計画法に 基づいた最適化計算を行うことにより，最適運用状態 を決定してきた。また，メンバシッブ関数のパラメー 夕の決定に際しては, 系統運用者にパラメー夕を決定 する情報を提供するために，最適潮流計算を含む単一 目的に扮ける最適化計算を行った。このような手法を 用いると，系統全体の状態拉よび各発電機特性を考慮 した高度な運用計画の立案が可能である。しかしなが ら，潮流計算とともに逐次行われる非線形最適化に基 づく手法では，対象とする系統の規模が增大するに伴 い所要計算時間が急激に増加することになる。また， 最適化計算を行うにあたり, 各評価指標についての全 時間帯総和を目的関数として設定しているため, 大規 模系統に扔いては計算機記憶容量が膨大になり，運用 計算の対象とすることができる時間带が極めて短時間 の場合に限られることになる。

以上のような点を考慮し, 本研究で開発された多目
的需給運用計算手法を実規模系統に適用し，オンライ ン運用システムに供するためには，計算時間の短縮お よび記憶容量の削減のため, 高速近似解法を導入する ことが必要となってきた。

そこで, 本研究で用いられる評価指標は主として二 次関数の形式で表現されていることに着目し，ラグラ ンジュの末定乗数法を用いて最適解を決定する手法を 導入する。この手法では, あらかじ設定された最適 条件を解くことによって最適解を得ることが可能であ るため, 計算時間が高速で大規模系統にも適用可能で 古る。また，本手法では動的負荷配分問題を静的負荷 配分と動的調整とに分離して考えているため，対象と する時間帯が比較的長時間にわたる場合でも適用が可 能である(11)。

〈5・2〉 ラグランジュ未定乗数法による最適解の 決定発電機出力に関する二次関数になっている目 的関数の最小値は, 送電損失を無視して考えた場合, ラグランジュの末定乗数法によって次のように解くこ とができる。

負荷需要 $P_{D}$ が与えられているときの各発電機の出 力配分は, 需給平衡を保ちながら目的関数を最小とす るように決定する。各発電機出力を $P_{1}, P_{2}, \cdots, P_{N}$ と し，そのときの各機の目的関数を $F_{1}\left(P_{1}\right), F_{2}\left(P_{2}\right), \cdots$, $F_{N}\left(P_{N}\right)$ とすれば，最適負荷配分問題は以下のように 記述される。

$$
\left.\begin{array}{l}
\min f=\sum_{i=1}^{N} F_{i}\left(P_{i}\right) \\
\text { subj. to } P_{D}=\sum_{i=1}^{N} P_{i}
\end{array}\right\}
$$

これに，ラグランジュの未定乗数法を適用し，

$$
\phi=\sum_{i=1}^{N} F_{i}\left(P_{i}\right)+\lambda\left(P_{D}-\sum_{i=1}^{N} P_{i}\right)
$$

を最小とする条件

$$
\frac{\partial \phi}{\partial P_{i}}=\frac{d F_{i}}{d P_{i}}-\lambda=0
$$

を解けば，次式により最適な発電機の出力配分が定ま

り，こ机は経済負荷配分に扔ける等 $\lambda$ 法である。

$$
\lambda=\frac{d F_{1}}{d P_{1}}=\frac{d F_{2}}{d P_{2}}=\cdots=\frac{d F_{N}}{d P_{N}}
$$

本論文の他の目的関数もすべて発電機出力の可分離 型の二次関数であるため，（3)式のファジィ決定関数 の最適化は上述の等 $\lambda$ 法をそのまま適用することに より，容易に最適解を得ることができる。

\section{〈5・3〉 負荷配分の動的調整(11)}

（1）平衡調整可能時点の決定 負荷变動方急激 なときは，ある発電機について給電指令值に対して応 答できない，すなわち応答速度制約を満足できない場 


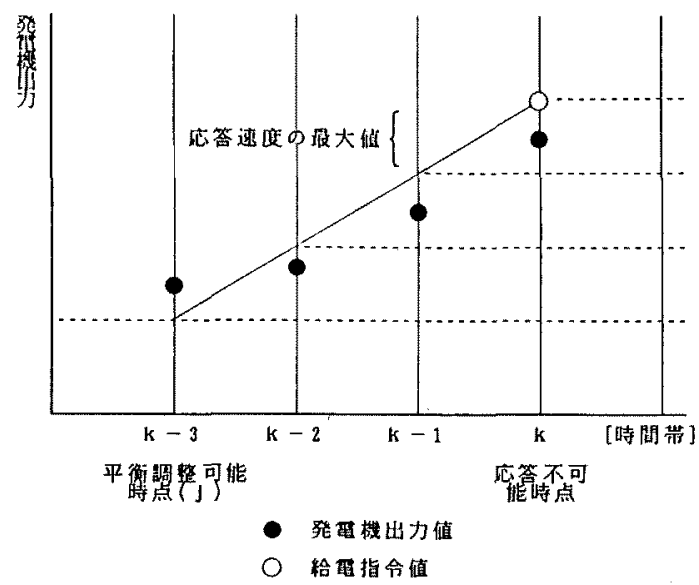

図 3 平衡調整可能時点の决定

Fig. 3. Determination of adjustable time zone.

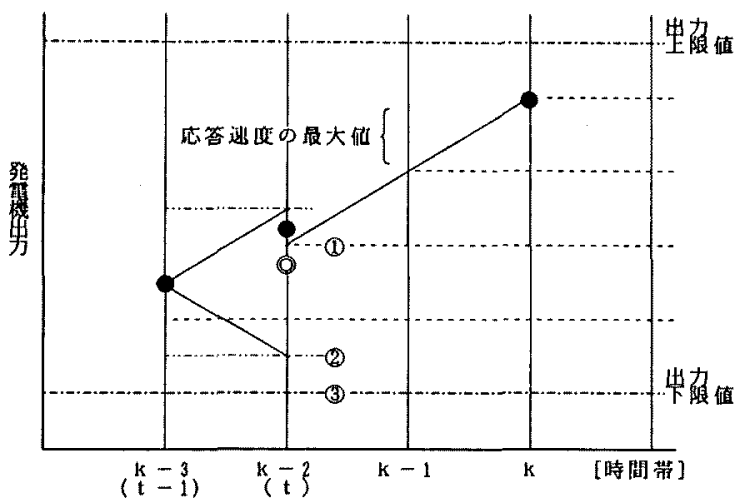

$\max [(1),(2),(3)] t, t$ 時点ての 出カソーン下限犆とする(負荷上界時)。

図 4 負荷配分の動的調整

Fig. 4. Dynamic adjustment of load dispatch.

合が生じることが考えられる。このような場合はこの 時点を「応答不可能時点」として定義し, 適当な時間 帯だけさかのぼって再計算することにより，応答不可 能時点で応答可能となるような動的調整を行うことが 必要である。このように再計算する場合，どの時点ま でさかのぼればよいかといった時点を決定する必要が ある。この時点，すなわち，応答速度制約を最大限使 ったときに応答不可能時点の給電指令值に応答できる ような, 最も新しい時間帯を「平衡調整可能時点」と 定義する。

平衡調整可能時点の決定には以下に示す判別式を用 いる。この判別式を満たす最大の $j$ を求め,この $j$ 時
点を平衡調整可能時点とする。

負荷增加時

$P_{G i(j)}>P_{G i(k)}-(k-j) \Delta P_{G i}$

負荷減少時

$P_{G i(j)}<P_{G i(k)}+(k-j) \Delta P_{G i}$

$P_{G i(k)}:$ 第 $k$ 時間帯の発電機 $i$ の有効出力 $(\mathrm{pu})$

$\Delta P_{\mathrm{C} i}:$ 発電機 $i$ 出力変化速度 $(\mathrm{pu} / 3 \mathrm{~min})$

$k$ : 応答不可能時点, $j:$ 平衡調整可能時点

（2）平衡調整可能時点加らの動的調整平衡調 整可能時点が決定されると, この平衡調整可能時点か ら応答不可能時点までの動的負荷配分計算を再び行 う。このときは, 各時間带の出力ゾーンを厳しく限定 することにより, 平衡調整可能時点から応答不可能時 点までの負荷調整を行う。

負荷上昇時の場合, このときの出カゾーンは,

(1) 応答不可能時点からの応答速度を考慮した点

(2) 調整可能時点加らの応答速度を考慮した点

(3) 発電機の出力下限值

のうち, 最も大きいものを，この時間帯の出カゾーン の下限値として設定して計算する。

また，負荷減少時の場合も同様に，

(1) 応答不可能時点からの応答速度を考慮した点

(2) 調整可能時点からの応答速度を考慮した点

(3) 発電機の出力上限值

のうち，最も小さいものを，この時間帯の出力ゾーン の上限值として設定して計算する。

従って, 動的調整では, 各時間带における発電機出 カゾーンを次のように設定しなおして再計算すればよ w。

（i） 負荷增加時の出力ゾーン下限値の設定

$$
\underline{P}_{u}(t)=\max \left(P_{G i(k)}-(k-t) \Delta P_{C i},\right.
$$$$
\left.P_{G i(t-1)}-\Delta P_{G i}, \underline{P}_{i}\right)
$$

（ii） 負荷減少時の出力ゾーン上限値の設定

$$
\begin{aligned}
\bar{P}_{u}(t)= & \min \left(P_{G i(k)}+(k-t) \Delta P_{G i},\right. \\
& \left.P_{G i(t-1)}+\Delta P_{G i}, \bar{P}_{i}\right) \cdots \cdots .
\end{aligned}
$$

$\bar{P}_{u}(t), \underline{P}_{u}(t)$ : 発電機 $i$ の出力ゾーン上下限

值 $(\mathrm{pu})$

$\bar{P}_{i}, \underline{P}_{i}$ : 発電機 $i$ の出力上下限值 $(\mathrm{pu})$

$\langle 5 \cdot 4\rangle$ 最適解決定手順 今回導入する手法は, 発電機応答速度制約付の静的負荷配分繰返し行い, 応答速度を満足できなくなった時点で調整可能時点ま でさかのほって再計算を行う。

〔Step 1〕各発電機特性等を示す係数など初期 データの読込み，および最適化対象期間の予測負荷デ 一夕の読込みを行う。 


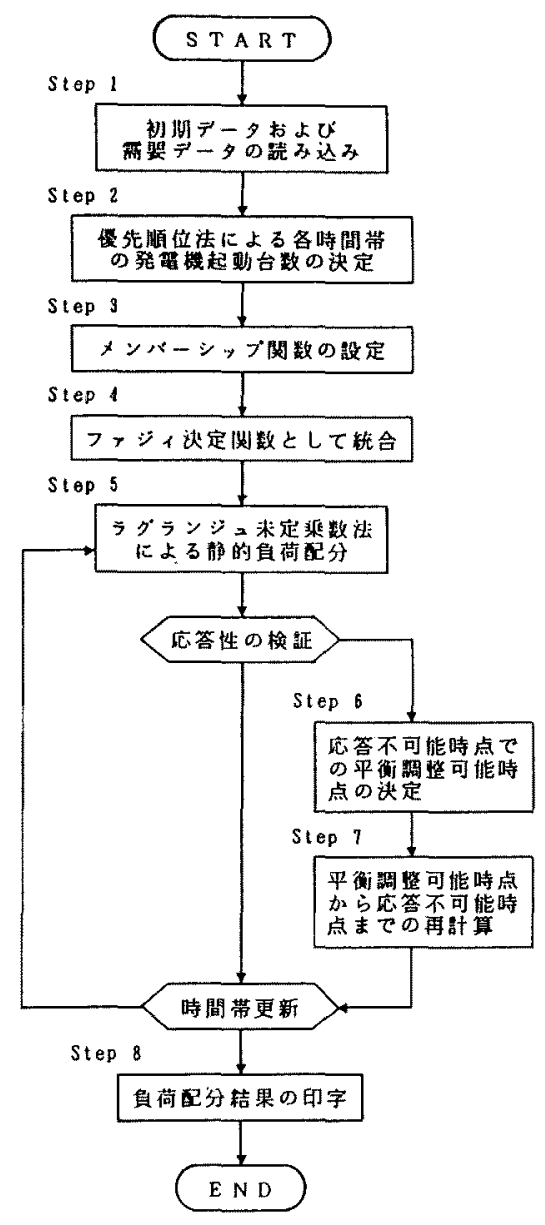

図 5 最適解決定手順

Fig. 5. Procedure to determine optimal solution.

（Step 2)与方られた負荷データに対して，優 先順位法に基づいた発電機の起動停止の決定を行う。

(Step 3) 需給平衡, 発電機出力上下限, 前時 間带からの発電機出力変化速度等の制約条件のもと で，各対象時間带について各目的の単一目的での最適 解を求め，この值を参考に各目的ごとのメンバシップ 関数を設定する。

(Step 4〕【Step 3]で設定されたメンバシップ 関数をファジィ決定関数として統合し，これを最適化 計算における目的関数として設定する。

（Step 5) 等 $\lambda$ 法による静的負荷配分計算を行 う。

〔Step 6〕発電機応答速度制約が满足できなく なった時点（応答不可能時点）が生じた場合, 調整が
可能な時点（平衡調整可能時点）を判別式により決定 する。応答速度が満足されていれば，時間帯を更新し て〔Step 5)に戻る。

[Step 7] 平衡調整可能時点加ら応答不可能時 点までの再計算を行ってから, 時間帯を更新し, 〔Step 5〕に戻る。

（Step 8）対象期間の全時間带について計算終 了後，負荷配分結果を出力する。

$$
\text { 6. シミュレーション }
$$

〈6・1〉適用系統 ここでは，これまでに述べて きたファジィ協調法に基ついた手法を関西電力の ELD 系統を模擬したモデル系統に適用し，その有効 性を検討する。考慮すべき発電・受電方式は，火力発 電, 水力発電, 原子力発電, 他社受電扔上び融通電力 としここれらより夐荷をになうものとする。しか し, 本手法では制御対象を給電指令が可能な火力発電 (50機) のみとしているため，火力発電機以外の設備 については系統データの取扱いに留意する心要があ り，以下のように取扱うこととする。

火力発電機の発電機特性は, 関西電力の実デー夕を 用い，これを給電指令の対象とする。原子力発電機は 定格出力で一定出力運転されているものとし, 試運転 中扔びスケジュール運転中の火力発電設備について は，実績値に基づいて発電機出力をデータとして与え る。更に，他社所有の発電設備からの受電抢よび相互 接続点に抢ける融通電力についても，実績值を基にデ 一夕として与える。

また，水力発電所は実際には制御が可能であるが， 本手法は火力発電機のみを出力制御の対象としている ため，これを実績值に基づいてスケジュール運転され ているものと仮定して取扱う。

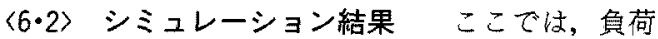
の立上り時である午前 8 時 30 分から年前 11 時までに ついて，本手法を関西電力の系統に適用した結果を示 す。

図6に示される1日の負荷パターン（火力発電機分 担分）に対して第 2 章で述べた優先順位法を用いるこ とにより，図7に示される起動台数が決定できる。運 用計算の対象となっている午前 8 時 30 分加ら午前 11 時まての起動台数の詳細を，図 9 に示す。

ここでは，通常の経済負荷配分 (ELD)により， 経済性のみを目的として運用した場合，ファジィ協調 法を適用して運用した場合（ファジィ協調法）につい てシミュレーションを行った。

図 10 およじ図 11 は, 各目的の満足度の和示して 


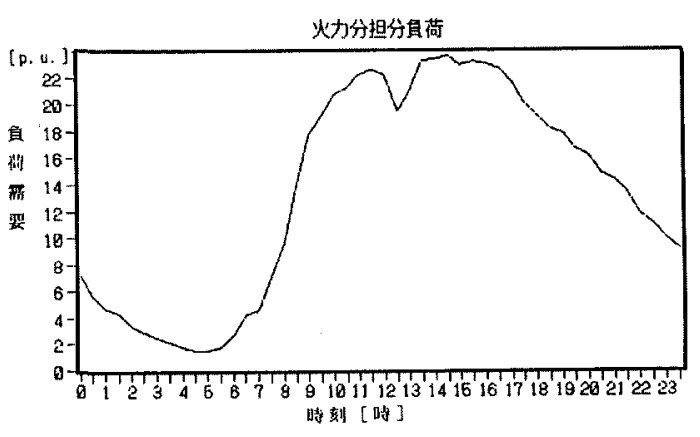

図 6 火力分担分負荷

Fig. 6. Load demand for thermal units.

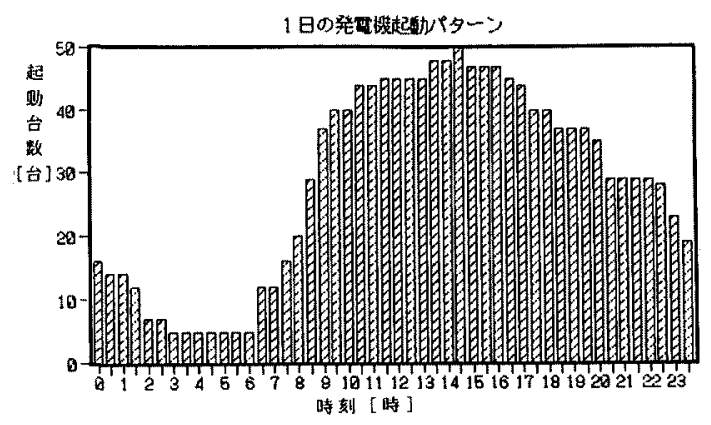

図 71 日の発電機起動パターン

Fig. 7. Unit commitment of the target day.

目菏需要 $(8: 38 \sim 11: 00)$

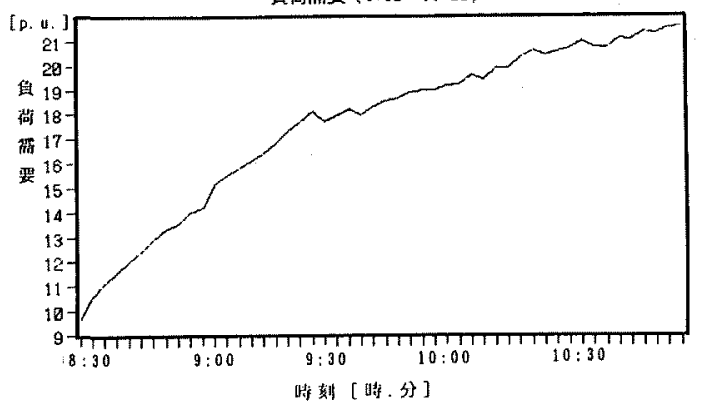

図 8 負荷需要 $(8: 30 \sim 11: 00)$

Fig. 8. Load demand $(8: 30 \sim 11: 00)$.

いる。ここで,メンバシップ関数のパラメータは, 電 力会社の方針や系統の状態などを考慮して意思決定者 が主観的に与えるあいまい量である。従って，各目的 が十分満足されているか否かは，軍用計画を立案する 意思決定者が会社の運用方針や運用状態を加味して主 観的に決定するものであり，メンバシップ関数の值に

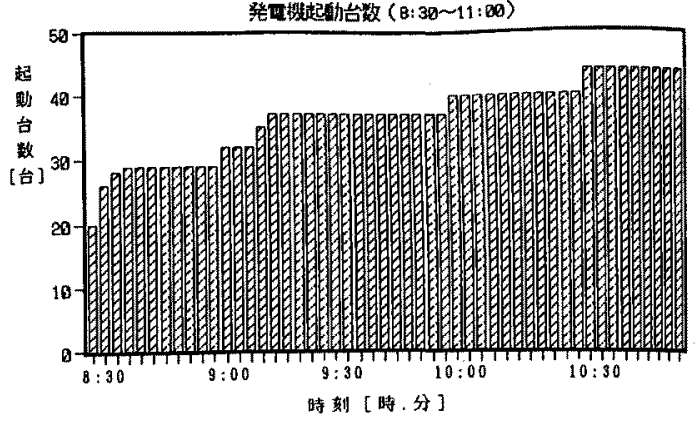

図 9 発電機起動台数 $(8: 30 \sim 11: 00)$

Fig. 9. Unit commitment $(8: 30 \sim 11: 00)$.

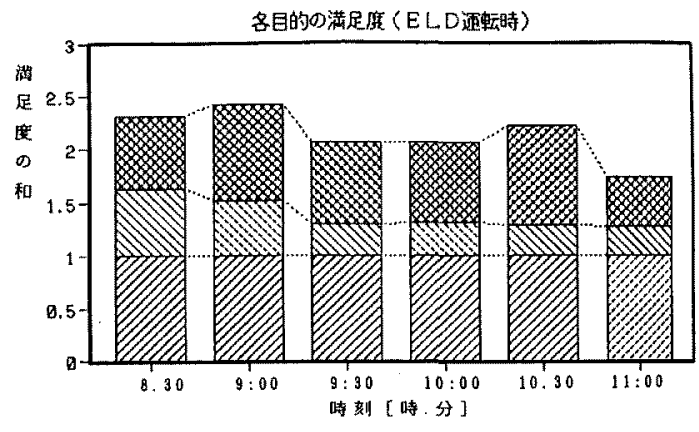

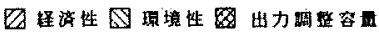

図 10 各目的の満足度 (ELD 運転時)

Fig. 10. The degrees of satisfaction (ELD).

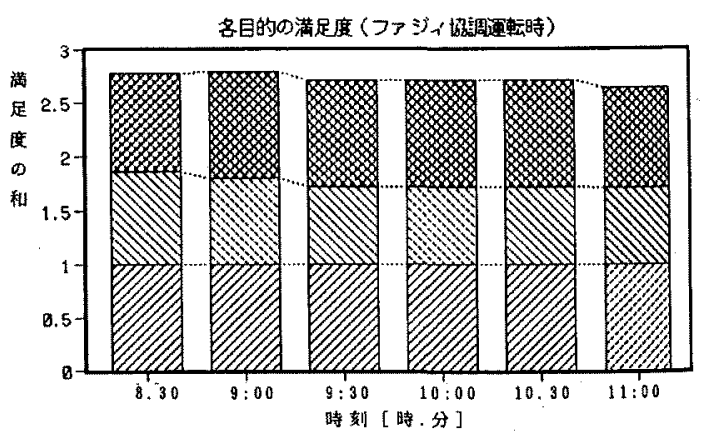

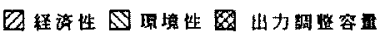

図 11 各目的の満足度（ファジィ協調運転時） Fig. 11. The degrees of satisfaction (fuzzy coordination).

よって定量的に示される。もしメンバシップ関数の 値が 1 に近ければ各目的が非常に満足されていると判 断し，メンバシップ関数の值が 0 に近ければ不十分で 


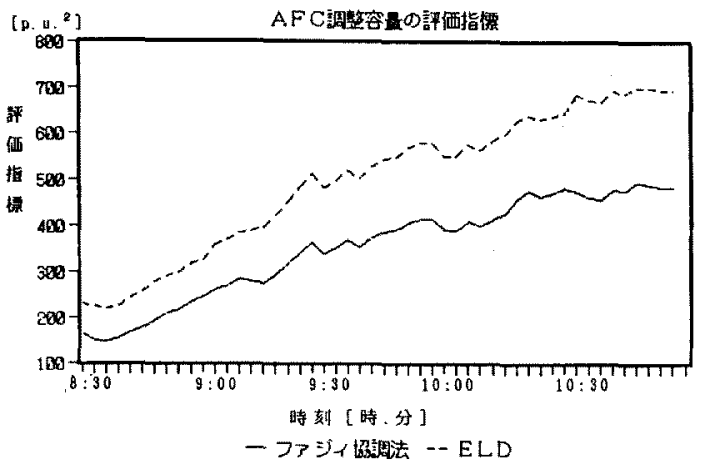

(a) 出力調整容量

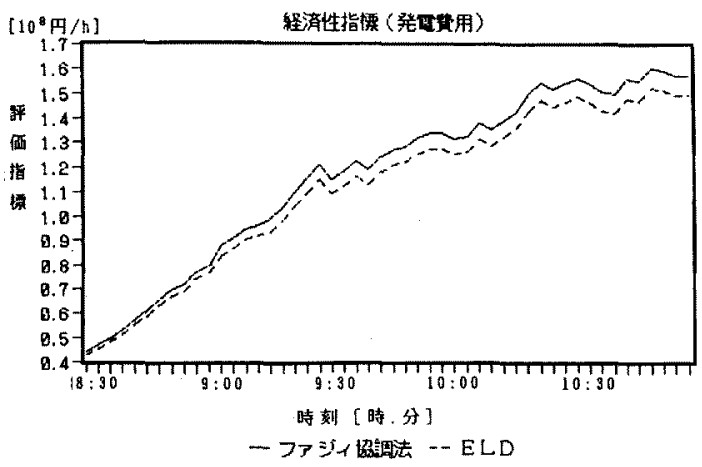

(b) 経斎性指摽

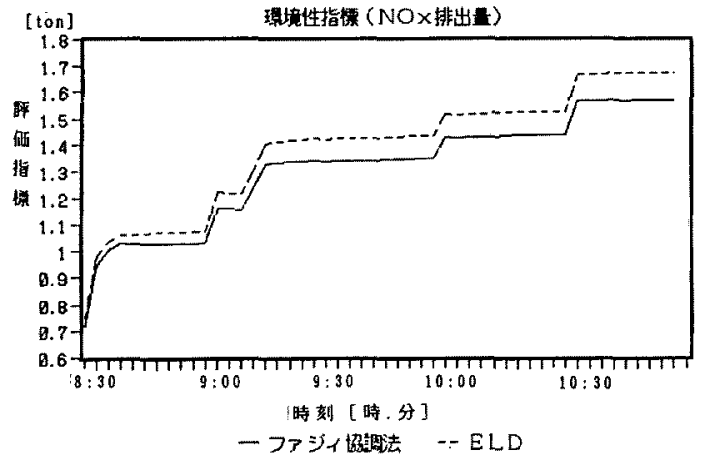

(c) 瑻境性指標

ファジィ協調法：ファジィ協調法を適用した場合 ELD：通常の経济負荷配分による遥用状熊

図 12 各目的の評価指標の值

Fig. 12. The values of the evaluation indices.

あると判断する。図 $100 \mathrm{ELD}$ 運用では経済性以外 の目的の満足度が著しく劣っているが, 図11のファ ジィ協調運用では経済性の満足度がわずかに劣っては いるが，他の目的が大きく改善されている。

図 12 は各評価指標の值を示している。これらの評
価指標は，〈4・1〉節で定義したように，值が小さいほ どその目的の達成度は高い。

これらの結果から, 通常のELD 運転に比べてファ ジィ協調法を適用した場合には, 経済性は多少犠牲に しても他の目的を大きく改善できている。また，各目 的の満足度の和もファジィ協調時には高い值を示して おり，す心゙ての目的をできるだけ満足させるといった 解が得られている。

また，計算時間については，非線形計画法に基づく 手法では大型計算機を用いて約 12 分かかっていたの に対し, 今回導入した高速近似解法による手法では, パーソナルコンピュータ(PC 9801-RX)を用いて, 約 3 分で計算が終了した。従って,大型計算機を利用する ことにより，3 分ごとに需給運用の計算を行い賁荷配 分を決定するオンライン運用への適用が可能である。

\section{7. まとめ}

本研究では，ファジィ協調法に基つ゚く電力系統の多 目的運用手法を害規模系統に適用するための高速近似 解法の導入を提案した。

実系統の適用にあたっては，計算時間の短縮，計算 機記憶容量の削減といった問題が生じていた。従っ て, 計算時間の短縮を図るため, 評価指標を二次関数 で近似し解を解析的に求める手法を導入した。また, 計算機記憶容量の削減のため, 全時間帯の目的関数を 統合した関数を扱うのではなく, 最適化計算を時間帯 ごとの静的配分計算と動的調整計算に分離して扱う手 法を導入した。この考光方によれば，原理的には，対 象期間が十分長い場合であっても解を得ることができ る。

また，発電機の起動台数についても，その運用期間 中不変であると仮定するのは実際的ではなく, 発電機 の起動停止を伴う長期にわたる運用計算をすることが 必要となっていた。そこで，実運用といった観点か ら，発電機の起動停止を考慮した手法を導入した。こ れにより，長時間にわたる運用計算を行うことができ る。

また，関西電力の系統に適用した結果，火力発電機 の運用において複数の目的を協調した妥当な解が得ら れていることが示された。

出力調整容量を考慮した電力系統の多目的最適運用 にファジィ協調手法を用い，高速近似解法を導入して 解くことによって，以下のような利点が得られた。

メンバシップ関数を用いたファジィ協調法を用いる ことにより，従来の最適化手法では取扱いが困難であ った多目的計画問題を効率的に解くことができる。ま 
た，各目的の評価指標を二次関数で表現すると，ファ ジィ決定関数も二次関数となるため, 最適条件を解く ことによって, 解を得ることができる。更に,メンバ シップ関数を用いて系統運用者の意思を反映させるこ とができるため, 運用者の経験・知識に基づいて適切 なメンバシップ関数を設定することができれば，より 実際に即した系統運用が可能である。

今後, 更に運用者の意思を適切に反映した運用を行 うためには, 適切な関数回帰手法を導入することによ り,メンバシップ関数の設定を行う手法を組込んでい くことが必要である。

(平成 4 年 2 月 3 日受付, 同 4 年 6 月 29 日再受付)

$$
\text { 文献 }
$$

（1）玄・井田：線形計画・目標計画プログラム（昭 59）電気書院

（2）松本・横山・新村：「ファジィ協調に基づく動的有効電力配分 法」, 電気学会電力技術研資, PE-89-182, 85 (平元)

（3）前川・安田・横山・大梱・水上：「AFC 調整容量を考虑した多 目的動的負荷配分」, 平 3 電気学会電力・エネルギー部門大会 (論文 I ) - 4, p.19

(4) T. Maekawa, K. Yasuda, R. Yokoyama, H. Ohtsuki \& Y Mizukami: "Fuzzy Coordination of Economy, Security and Quality in Power System Generation Control", Third International Conference on Power System Monitoring and Control IEE U. K., p. 174 (1991)

（5）前川・安田・横山・大梘, 水上：「ファジィ協調法に基づく多 目的運用の実規模系統への適用」, 電気学会電力技術研資, $P E-91-3,21$ (平 3 )

（6）関根・林・芹沢・豊田・長谷川：電力系統工学（昭 54） コロ 十社

（7）坂和・湯峯・南後：「多目的非線形計画問題に対する対話型つ アジィ意志決定」, 信学論 A, J66-A, 1243 (昭 58-12)

(8) A. M.Sasson: "Nonlinear Programming Solution for Load-Flow, Minimum Loss and Economic Dispatching Problems", IEEE Trans. Power Apparatus Syst., PAS-88, 399 (1969)

(9) M. R. Gent \& J. W. Lamont: "Minimum-Emission Dis patch", ibid., PAS-90, 2650 (1971)

（10）北内・餘利野・田村：「Feasibility の高いオンライン火力機経 済負荷配分法」, 電学論 B, 107, 131 (昭 62-3)

（11）周・安田・横山：「オンライン動的負荷配分のための一手法」, 平 3 電気学会全大, p. 246

（12）青木・横山：「発電機の応答速度を考慮した動的な経済負荷配 分法」, 電気学会電力技術研資, PE-86-99, 81 (昭 51)

(13) R. Yokoyama, S. H. Bae, T. Morita \& H. Sasaki "Multiobjective Optimal Generation Dispatch Based on Probability Security Criteria", IEEE Trans. Power Syst., 3, No. 1, 317 (1988)

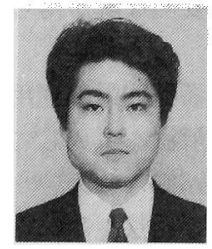

\section{前川友哉 (正員)}

昭和 42 年 6 月 20 日生。平成 4 年 3 月 東京都立大学大学院工学研究科電気工学 専攻修士課程修了。同年 4 月関西電力 (株) 入社。神戸電力所制御通信課に勤 務, 現在に至る。主として, 大規模電カシステムの最適運 用に関する研究に従事。

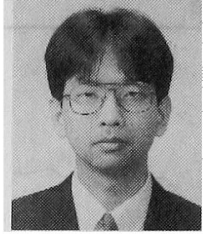

\section{安 田 恵一郎 (正員)}

昭和 35 年 9 月 10 日生。平成元年 3 月 北海道大学大学院工学研究科電気工学専 攻博士課程修了。同年 4 月東京都立大学 工学部助手, 3 年 4 月同工学部助教授と なり，現在に至る。主として，大規模システムの計画・運 用・制御に関する研究に従事。工学博士。OR学会, シス テム制御情報学会, 電気設備学会会員。

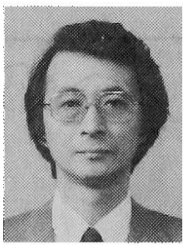

\section{横 山 隆 - (正員)}

昭和 19 年 8 月 25 日生。 48 年 3 月早 稲田大学大学院理工学研究科電気工学専 攻博士課程修了。 49 年 4 月(株)三菱総 合研究所入社。53 年 9 月東京都立大学 工学部助教授，平成元年 4 月同教授となり，現在に至る。 主として, 大規模システムの計画・運用・制御, ディジタル システム制御, エキスパートシステム, ファジィ理論応用 に関する研究に従事。工学博士。計測自動制御学会, シス テム制御情報学会, 電気設備学会, CIGRE, IASTED, IEEE 会員。

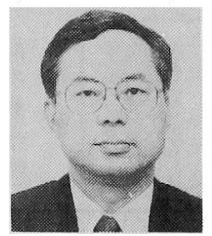

$$
\text { 水上雄 一 (正員) }
$$

昭和 18 年 10 月 15 日生。 42 年 3 月東 京大学工学部電子工学科卒業。 42 年 4 月関西電力(株) 入社。平成元年 12 月同 社総合技術研究所主席研究員となり, 現 在に至る。主として, 電力系統の運用およびその技術開発 に従事。

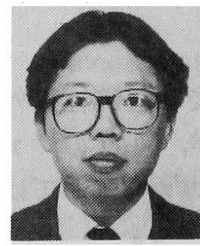

横山 尚 登 (正員)

昭和 30 年 2 月 21 日生。 48 年 3 月兵 庫県立兵庫工業高等学校電気科卒業。同 年 4 月関西電力 (株) 入社。現在, 同社系 統運用部系統技術課に勤務。主として, 電力系統の解析および安定化技術の開発に従事。 